\title{
マグネトロン直結型マイクロ波誘起プラズマ光源の 試作とその発光特性
}

\author{
前田愛明*.小松敏行*. 荒木 勉* · 内田照雄** \\ *徳島大学工学部機械工学科 徳島市南常三島町 2-1 ( \\ **摂南大学工学部物理学教室＼cjkstart寝屋川市池田中町17-8（テ572） \\ （1997年 1 月25日 受理） \\ キーワード : マイクロ波誘起プラズマ (MIP), インピーダンス整合, 同軸型マッチング用アダプタ
}

Design and performance of a stable microwave-induced plasma light source directly coupled with a magnetron

\author{
Yoshiaki MAedA*, Toshiyuki Komatsu*, Tsutomu ARAKI*, and Teruo UCHIDA** \\ *Department of Mechanical Engineering, Faculty of Engineering, \\ University of Tokushima, Minamijousanjima, Tokushima, 770 \\ **Department of Physics, Faculty of Engineering, Setsunan University, \\ Ikedanakamachi 17-8, Neyagawa, Osaka, 572
}

(Received January 25, 1997)

\section{1. はじめに}

マイクロ波誘起プラズマ (Microwave Induced Plasma, 以下 MIP と略す) 光源は発振周波数 $2450 \mathrm{MHz}$ のマイク 口波を円筒型空洞共振器で共振させ, 共振器中央部に通し た放電管中でアルゴン, ヘリウム, 窒素などの気体を高温 プラズマ化する無電極放電プラズマ励起光源である. 1976年に Beenakker が $\mathrm{TM}_{010}$ モード共振器を開発し1), これによって大気圧下でのプラズマ生成が可能となったた め, MIP は発光分光分析用の励起光源や質量分析用のイ オン源として注目されるようになった．MIP 光源の特長 は,

(1) 励起，イオン化効率が高い，

(2) 必要とする電力やガス流量が少ない,

(3) 装置がコンパクトかつシンプルである, などが挙げられる。

マイクロ波出力が $200 \mathrm{~W}$ 以下の低出力 MIP 光源では, 通常, マイクロ波発生装置（マグネトロン）から共振器へ のマイクロ波伝送に同軸ケーブルを使用する．伝送電力が 大きいので, 大口径 (外径 $10 \mathrm{~mm}$ 以上) のケーブルが望 ましいが，大口径ケーブルはフレキシビリティに欠け，装
置が大型化する. さらに，この方法では共振器と同軸ケー ブルのインピーダンス整合が困難であり, 共振器からマイ クロ波の反射が起こる. そのため入射波と反射波の干渉で ケーブル内に定在波が発生し，マイクロ波の伝送効率が悪 化するだけでなく，マグネトロンや同軸ケーブルを焼損す る恐れがある.われわれの経験では, 外径 $10 \mathrm{~mm}$ の同軸 ケーブル（藤倉電線 RG-8U : 特性インピーダンス $52 \Omega$ ) を使用した場合，マイクロ波出力が $100 \mathrm{~W}$ 程度でも定在 波発生によって, ケーブルの導体部や絶縁部が局所的に熱 変形した，そのため同軸ケーブルの特性インピーダンスが 次第に変化し， ますすす損失が大きくなって熱発生が増加 するという悪循環が生じ，時間的に安定したプラズマ発光 を得ることが困難であった。このような定在波の影響を軽 減するため, 逆伝播回避用サーキュレータと, サーキュレ 一タからの反射波吸収用に大容量アッテネータを常用して いる. しかし, これらは MIP 装置を複雑化し, 電気的損 失の大きいケーブル接続部が増えるなど, 新たな問題発生 要因になりかねない.

そこで我々はマグネトロンと共振器との間を金属円筒と 同軸中心導体で構成された同軸型マッチング用アダプタで 直結する方法を考案した. アダプタの線路長を変えること 
で伝送路のインピーダンスが変化するため, 任意の負荷イ ンピーダンス值に対応できる. しかし, 現実の共振器に扔 いては, プラズマ状態や試料の有無などさまざまな要因で 負荷インピーダンスが変化するため, 計算によってアダプ タの最適線路長を決定できない，そこで，いくつかの長さ のアダプタを製作し，実験的に最適条件を求めた．その結 果, 線路長は $80 \mathrm{~mm}$ が最適となった。 また, 同軸型マッ チング用アダプタは機械的にも充分な強度を持たせ, マグ ネトロンと共振器を一体化できるよう設計した結果, 機械 的にも電気的にもきわめて安定な光源となった。

本論文ではマイクロ波伝送の高効率化を目的とした直結 型 MIP 光源について, 同軸型マッチング用アダプタの線 路長を変化させた場合の共振器内電界強度, プラズマ発光 強度, 励起温度の測定結果および最適アダプタ使用時のプ ラズマ発光強度の安定性について述べる。

\section{2.マイクロ波伝送回路}

本研究では同軸型マッチング用アダプタの線路長を段階 的に変えてインピーダン久整合に近づけ, マイクロ波伝送 の高効率化を図った。 その原理を述べるにあたり, 共振器 を負荷，同軸型マッチング用アダプタを伝送路とする一般 的なマイクロ波伝送回路を Fig. 1 に示す.

負荷インピーダンスを $Z_{R}$, 伝送路の特性インピーダン 久を $R_{C}$ とすると, 負荷端から距離 $l$ の点での電压 $\left(V_{l}\right)$ 上電流 $\left(I_{l}\right)$ は以下の式で表せる.

$$
\begin{aligned}
& V_{l}=V_{i} \exp (j \beta l)+V_{r} \exp (-j \beta l) \\
& I_{l}=\left[V_{i} \exp (j \beta l)-V_{r} \exp (-j \beta l)\right] / R_{C}
\end{aligned}
$$
ただし，

$$
V_{i}=I_{R}\left(Z_{R}+R_{C}\right) / 2
$$



Fig. 1 Change of the standing wave in a transmission line due to the line length.

$$
\begin{aligned}
& V_{r}=I_{R}\left(Z_{R}-R_{C}\right) / 2 \\
& \beta: \text { 位相定数 }
\end{aligned}
$$

式(1)，(2)の第一項は入射波，第二項は反射波を表し， 伝送路の入力インピーダンス $Z_{l}$, すなわち $\mathrm{A}-\mathrm{A}^{\prime}$ から右を みたインピーダンスは次式で表せる。

$$
\begin{aligned}
Z_{l} & =V_{l} / I_{l} \\
& =R_{C}\left[Z_{R}+j R_{C} \tan (\beta l)\right] /\left[R_{C}+j Z_{R} \tan (\beta l)\right]
\end{aligned}
$$

式(3)から, 線路長lによって入力インピーダンス $Z_{l}$ が 変化することがわかる，この伝送路のインピーダンス変換 作用を利用して，負荷のみかけのインピーダンスを $R_{C} に$ 等しくすれば反射波を抑制することができ，高効率のマイ クロ波伝送が可能になる.

\section{3. 装置}

\subsection{MIP 光源}

\subsubsection{TM010 モード共振器}

本研究で製作した同軸型マッチング用アダプタおよび $\mathrm{TM}_{010}$ モード共振器の軸方向断面図をFig. 2 に示す。共

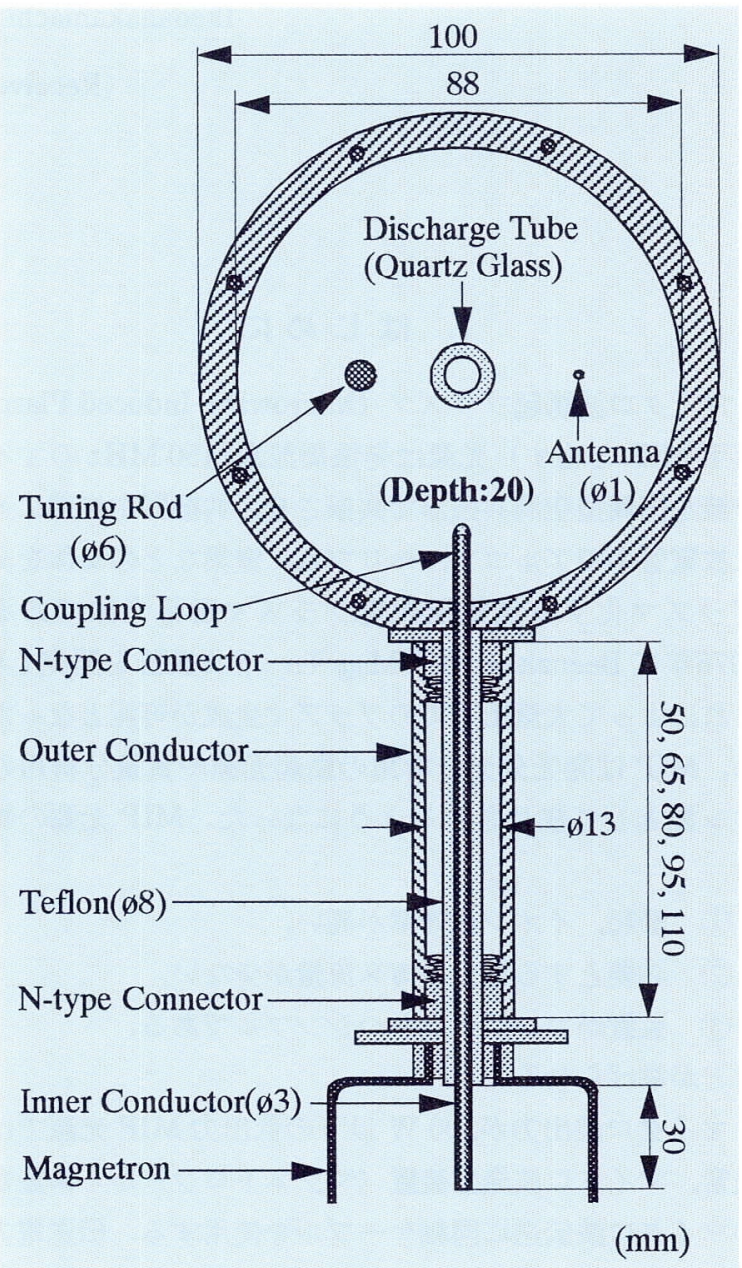

Fig. 2 Inside of the resonance cavity and the coaxial adapter. 
振器の深さはプラズマガスや試料の滞在時間を考慮して $20 \mathrm{~mm}^{2)}$ とし, 内径は有限要素法による共振器解析の報 告3) から $88 \mathrm{~mm}$ とした. 共振器内部には共振周波数調整 用の同調棒抢よび電界強度測定用のアンテナを取り付け た. 共振器内部をFig. 3 に示す.

放電管は，その中心部にプラズマを安定保持する目的で Fig. 4のように石英ガラス管を二重に配置した ${ }^{3)}$. 各放電 管の内外径は, 内側放電管の内径を $2.0 \mathrm{~mm}$, 外径を 4.0 $\mathrm{mm}$, 外側放電管の内径を $4.5 \mathrm{~mm}$, 外径を $6.0 \mathrm{~mm}$ とし た.

\section{1 .2 同軸型マッチング用アダプタ}

同軸型マッチング用アダプタの導体部は電気伝導度の高 い銅を用い, 内部導体の直径を $3 \mathrm{~mm}$, 外部導体の内径を $13 \mathrm{~mm}$ ，特性インピータ゚ンスを $88 \Omega$ とした。また絶縁部 には耐熱性のあるテフロンを使用した（Fig. 2)。したが って同軸ケーブルのようなフレキシビリティはないが，耐 熱性に優れて抢り，熱による導体部および絶縁部の変形は 起きにくい，線路長は，伝送路内で共振が起きないよう， マイクロ波 1 波長以下の長さ（120 mm 以下）とし，1/8 波長 $(15 \mathrm{~mm})$ ごとに $50,65,80,95,110 \mathrm{~mm}$ の計 5 本を 製作した。これは定在波の山または谷が繰り返される間隔 が，使用するマイクロ波の半波長に相当し，さらに伝送路 の入力インピーダンスが $1 / 4$ 波長ごとに誘導性と容量性を 繰り返すことから (Fig. 1)， その半分の1/8波長ごとに線 路長を変えてインピーダンス整合に近づけることをねらい としている. 製作した各同軸型マッチング用アダプタを Fig. 5 に示す.

\section{2 分析システム概要}

本 MIP 光源および分析システムの概略図を Fig. 6 に示 す. 定電圧電源から定常的に一定電力がマグネトロンに供 給される.マグネトロン（松下電子応用機器 TO75-01：

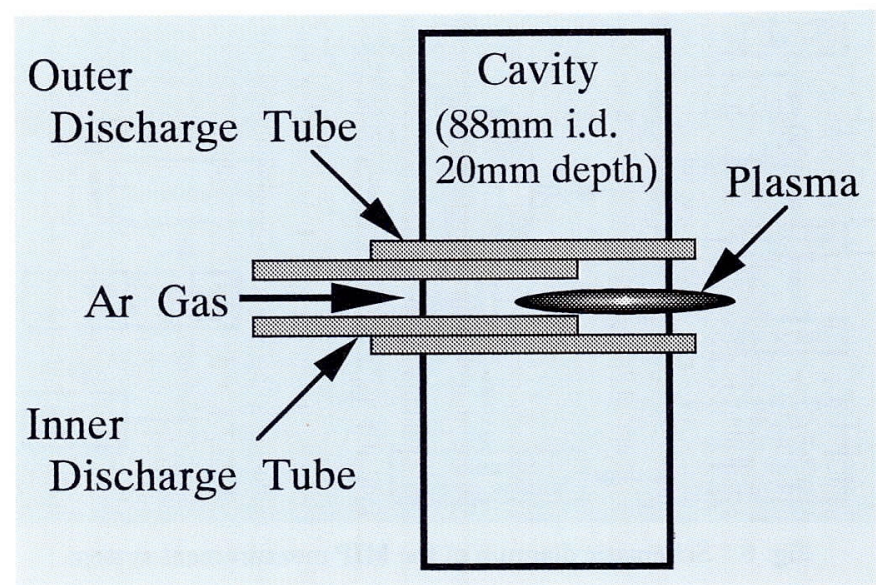

Fig. 4 Schematic view of the resonance cavity with a double discharge tube.

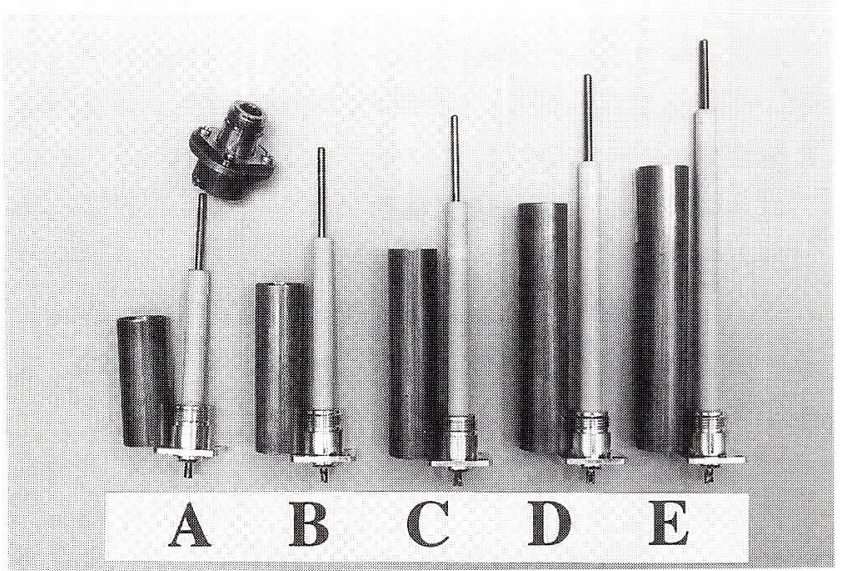

Fig. 5 Five coaxial adapters of different length to determine the impedance matching.

A: 50, B: 65 , C: 80 , D: 95 , E: $110 \mathrm{~mm}$

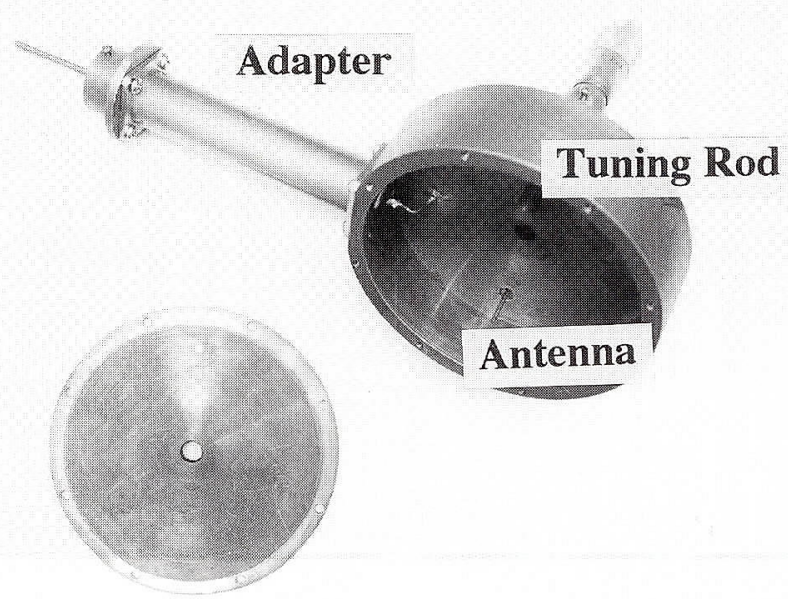

Fig. 3 Direct view of the inside resonance cavity. 


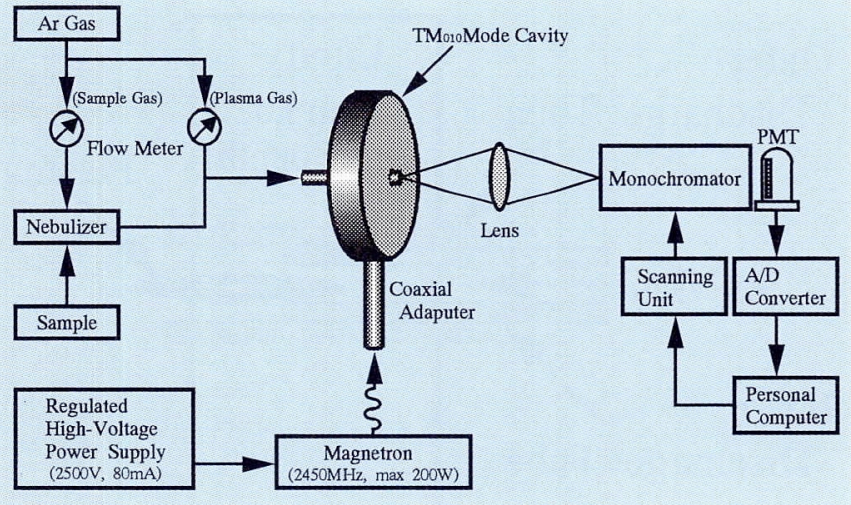

Fig. 6 Schematic diagram of the MIP measurement system.

発振周波数 $2450 \mathrm{MHz}$ ，最大出力 $200 \mathrm{~W}$ ) で発生したマイ クロ波は，同軸型マッチング用アダプタを介して共振器へ 伝送される。 $\mathrm{TM}_{010}$ モード共振器は中心軸上で電界強度 が最大になり，その強電界によってプラズマが生成する. ボンベから出た高純度アルゴンガス (99.99\%) は 2 経路 に分岐され，一方はプラズマの生成（プラズマガス），他 方はネブライザ (ICP 用同軸型ネブライザ) による溶液 試料の霧化（キャリヤガス）に使用される。この 2 経路 のガスは予混合され, 共振器中央部の放電管内へ送られ る. 各ガス流量の最適值は，プラズマガス0.6 l/ $\mathrm{min}$, キ ヤリヤガス $0.4 \mathrm{l} / \mathrm{min}$ であった。

プラズマの観測は放電管の軸方向から行うため, プラズ マ先端部の発光をレンズによって分光器（島津製作所 $\mathrm{MAF}$ : エバート型, 焦点距離 $0.5 \mathrm{~m}, 1200$ 本 $/ \mathrm{mm}$ ) 入射入 リット上に結像する．受光素子には光電子增倍管（浜松木 トニクスR106：サイドオン型）を使用し，その出力信号 は $\mathrm{AD}$ 変換後コンピュータで解析される.

マグネトロンの出力はカタログ記載の印加電圧一出力特 性カーブを基に, 使用印加電圧から求めた．今回は低出力 時の安定性を中心に調査する目的で, 出力を $100 \mathrm{~W}$ に設 定した。

\section{4. 測定および考察}

\section{1 共振器内電界強度}

各線路長に対する共振器内電界強度を比較するため, BNC 型コネクタに取り付けたアンテナ（長さ10 mm）を 共振器内へ挿入し，サンプリングオシロスコープで電圧信 号をモニタした．その結果，Fig. 7 に示すように線路長が $80 \mathrm{~mm}$ のとに共振器内電界強度は最大となった。

\section{2 プラズマ発光強度}

各線路長に対するプラズマ発光強度を測定した。ここで は試料導入をせず，Ar原子線 $427,217 \mathrm{~nm}$ について，時定 数 0.5 秒の検出器によって 10 秒間測定を行った。その平均 值と変動をプロットした結果, Fig. 8 に示すように線路長 $80 \mathrm{~mm}$ のとき゚ラズマ発光強度が最大となった。

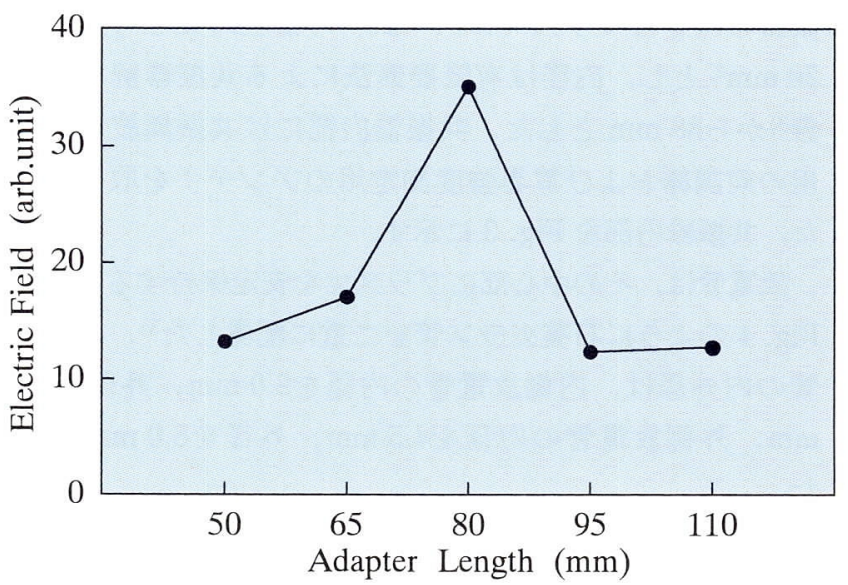

Fig. 7 Change of the electric field in the resonance cavity with respect to the adaptor length at microwave power of $100 \mathrm{~W}$.

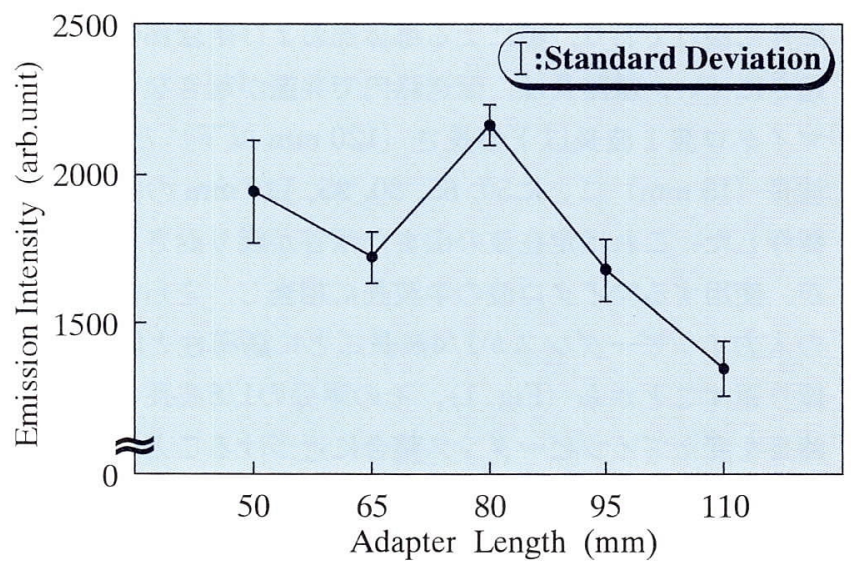

Fig. 8 Change of the emission intensity of $\mathrm{Ar}$ (I) 427.217 $\mathrm{nm}$ line with respect to the adapter length. Microwave power: $100 \mathrm{~W}$.

\section{3 プラズマ励起温度 ${ }^{4,5}$}

温度はプラズマの特性を知る上で最も重要な要素の一つ である，そこで各線路長に対するプラズマ励起温度を測定 した. 分光学的に励起温度を求めるにあたり, 異なるエネ ルギー準位の原子密度分布がボルツマン分布に従い，プラ ズマが均一で自己吸収が無いと仮定する。そしてプラズマ 内の中性粒子に打いて，単位時間に準位 $i$ から準位 $j へ の$ 遷移によって放射される光強度 $I_{i j}$ の式, $I_{i j}=n\left(g_{i} / Z\right) A_{i j}$ $h v \exp \left[-E_{i} /(k T)\right]$ を変形し両辺対数をとり次式を得る.

$$
\log \left[I_{i j} /\left(g_{i} A_{i j} v\right)\right]=C-E_{i} /(k T)
$$

ここで，

$$
\begin{array}{ll}
n: \text { 粒子の密度 } & g_{i}: \text { 準位 } i の \text { 多重度 } \\
Z: \text { 分配関数 } & h: \text { プランク定数 }
\end{array}
$$

$A_{i j}$ : 準位 $i$ から $j$ への遷移確率 $v$ : 放射さ机る光の振動数

$E_{i}$ : 準位 $i$ の励起エネルギー $k$ : ボルツマン定数
$T:$ 温度
$C:$ 定数 
$g_{i}, A_{i j}$ 抢よび $E_{i}$ が既知である複数の同一元素久ペクトル 線の相対強度を測定し, 繸軸に左辺を, 横軸に $E_{i}$ をとっ て各点をボルッマンプロットすると(4)式は直線となり, その勾配から励起温度 $T$ を求めることができる。本研究 では各線路長に対して Fig. 9 に示す Ar 原子線の相対強度 と, Table 1 に示す各值を用いて励起温度を求めた。その 結果をFig. 10に示す。最も励起温度が高いのは線路長80 $\mathrm{mm}$ のときであり，これは前述した共振器内電界強度抢よ びプラズマ発光強度の測定結果と一致している。

したがって以上の則定結果を総合すると，線路長 80 $\mathrm{mm}$ の同軸型マッチング用アダプタが共振器とインピーダ ソ久整合に最も近く，マイクロ波伝送の効率が最良の状態 にあるといえる。

\section{4 プラズマ発光強度の安定性}

マイクロ波伝送の効率が良くなれば，プラズマ発光強度 女安定すると考えられる。旮こで各アダプタについて， $\mathrm{Ar}$ 原子線 $427.217 \mathrm{~nm}$ の発光強度を 100 秒間記録し, 強度 の変動を調査した．Fig. 11にアダプタ長 $80 \mathrm{~mm} \mathrm{と50} \mathrm{mm}$ の変動の様子を示すが， $80 \mathrm{~mm}$ の場合，発光強度が大き く，かつ変動が小さくなっていることがわかる。このよう にして各アダプタごとに測定したプラズマ発光強度の変動

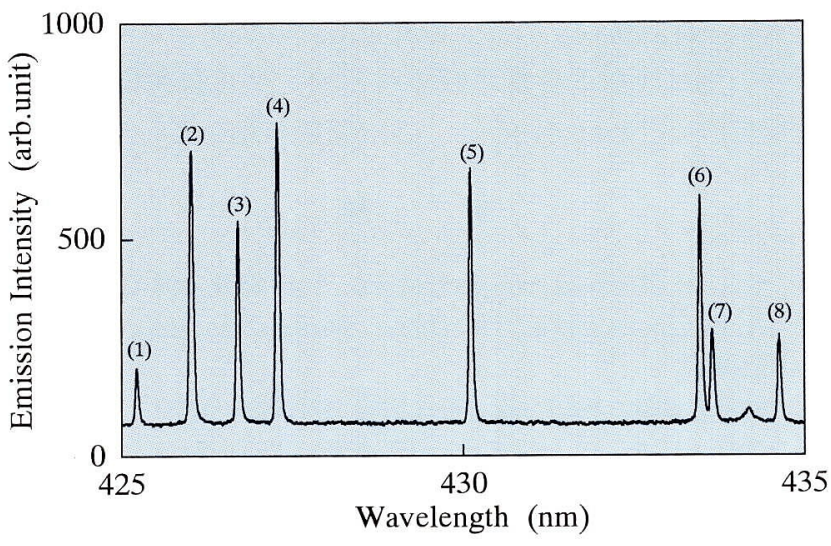

Fig. 9 Emission spectra of the argon gas between 425 and $435 \mathrm{~nm}$ obtained from the MIP. Microwave power: $100 \mathrm{~W}$, adapter length: $80 \mathrm{~mm}$.

Table 1 Argon transitions used for excitation temperature measurements

\begin{tabular}{ccccc}
\hline No. & $\lambda(\mathrm{nm})$ & $E_{i}\left(\mathrm{~cm}^{-1}\right)$ & $g_{i}$ & $A_{i j}\left(10^{-7} \mathrm{sec}^{-1}\right)$ \\
\hline$(1)$ & 425.118 & 116660 & 3 & 0.0089 \\
$(2)$ & 425.936 & 118871 & 1 & 0.3665 \\
$(3)$ & 426.629 & 117184 & 5 & 0.0265 \\
$(4)$ & 427.217 & 117151 & 3 & 0.0688 \\
$(5)$ & 430.010 & 116999 & 5 & 0.0318 \\
$(6)$ & 433.356 & 118469 & 5 & 0.0506 \\
$(7)$ & 433.535 & 118459 & 3 & 0.0308 \\
$(8)$ & 434.545 & 118408 & 3 & 0.0273 \\
\hline
\end{tabular}

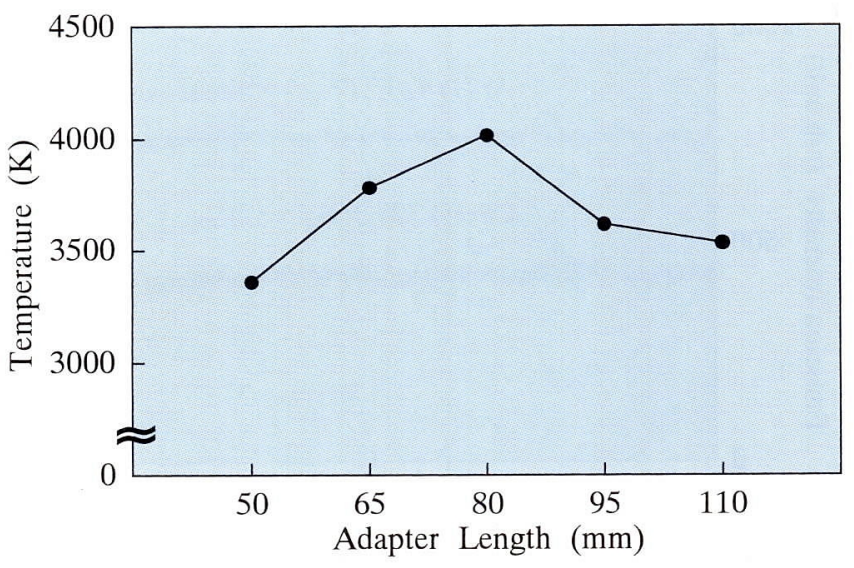

Fig. 10 Relation between the excitation temperature of argon plasma and the adaptor length without sample introduction. Microwave power: $100 \mathrm{~W}$.

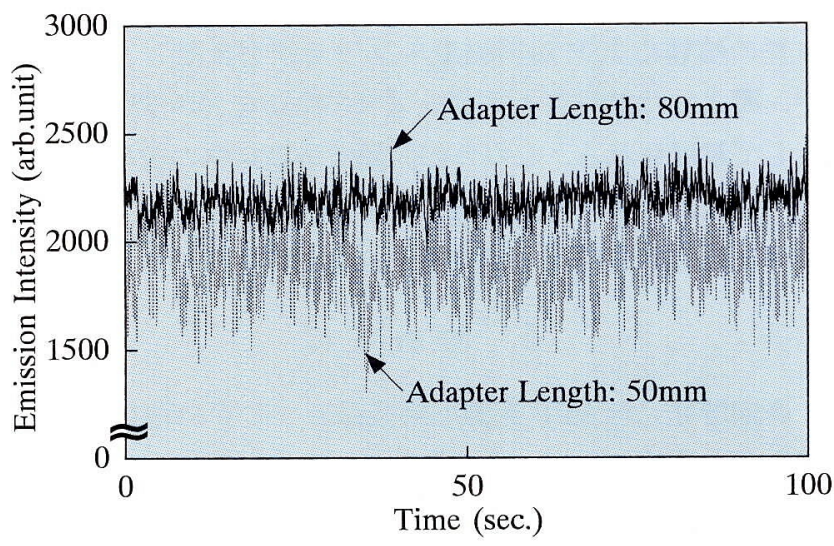

Fig. 11 Emission stability of $\operatorname{Ar}$ (I) $427.217 \mathrm{~nm}$ line for 100 sec with adapter length of 50 and $80 \mathrm{~mm}$. Microwave power: $100 \mathrm{~W}$.

幅を，エラーバーとしてFig. 8 に記入した.この結果か ら80 mm のアダプタはマイクロ波伝送の効率が最大で, 発光変動が最小上なり, 本装置に扮いては最適の線路長で あるといえる。

次に線路長 $80 \mathrm{~mm}$ のアダプタを使用し，アルゴンスペ クトル抢よ゙カルシウムスペクトルの発光強度を20分間 測定した結果を Fig. 12に示す（検出器時定数0.5秒）。 ルゴンスペクトル線の測定に打いては溶液試料を導入せ ず, $\mathrm{Ar}$ 原子線427.217 nm を観測し, カルシウムスペクト ルでは試料として150 ppmのカルシウム溶液索入し, Ca イオン線393.366 nm の発光を観測した.

Fig. 12から各発光強度の相対標準偏差は, Ar 原子線が $\pm 1.6 \%, \mathrm{Ca}$ イオン線が $\pm 3.8 \%$ となった。 $\mathrm{Ar}$ 原子線は， 通常の測定時間に対して充分長い20分間でも安定した発 光強度を持続しているが，Caイオン線は，Ar原子線より も発光強度変動が大きい. 加えて時間の経過に伴い発光強 度がやや低下傾向にあることから，この原因溶液試料の 


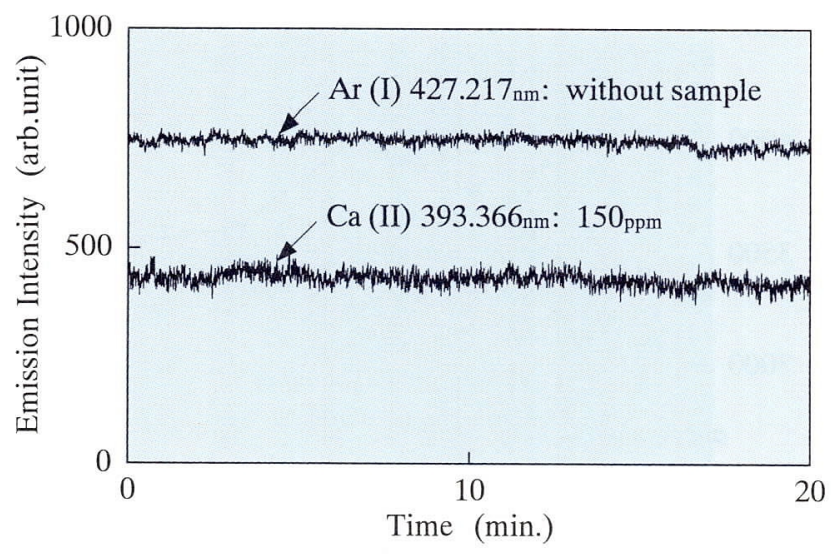

Fig. 12 Emission stability of $\mathrm{Ar}$ (I) $427.217 \mathrm{~nm}$ and Ca (II) $393.366 \mathrm{~nm}$ lines for $20 \mathrm{~min}$. Microwave power: $100 \mathrm{~W}$, adapter length: $80 \mathrm{~mm}$.

直接噴霧導入による影響と考えられる，具体的には，溶液 試料の噴霧に ICP 用同軸型ネブライザを流用している点 や，導入した試料によるプラズマの泠却などが変動の原因 として挙げられる。これらの問題は溶液試料の脱溶媒抢よ び，超微細霧化が可能な超音波ネブライザの使用など，試 料導入系の改良によって改善されると考えられる.

\section{5.おわりに}

今回開発した MIP 光源の特長は, マイクロ波伝送の高 効率化を目的として, マグネトロンと共振器を同軸型マッ チング用アダプタで直結したことにある。これまで不可欠 であったサーキュレータとアッティータを取り外し，同軸 ケーブルに代えて同軸型マッチング用アダプタで直結した ことは，マイクロ波伝送の高効率化に加えて装置の小型化 にも貢献している. 今回, 共振器とのインピーダンス整合 をとるために線路長の異なる5 本のアダプタを製作し， 共振器内電界強度, プラズマ発光強度, 励起温度の測定を 行った. その結果, いずれの測定に抢いても線路長 80 $\mathrm{mm}$ のときに良好な結果を示した．このとき，共振器と同 軸型マッチング用アダプタのインピーダンス整合が最もと
れて抢り，効率よくマイクロ波伝送が行なわれている。 た，本アダプタは耐熱性にも優れているため，従来の同軸 ケーブルに比べて熱变形による特性インピーダンスの変化 が起きにくく，長時間安定したプラズマ発光を得ることが できた。

しかし, 本方法はシンプルである反面, 微妙なインピー ダンスチューニングが行えず，完全なインピーダンス整合 を実現することは困難である。今回の装置では線路長を $15 \mathrm{~mm}(\lambda / 8)$ 毎に変化させ，最適長 $80 \mathrm{~mm}$ を得たが， 完全な整合を行うためには80 mm 近傍をさらに細かく分 割して調査する必要がある。市た，たとえこのようにして 最適線路長が決定できたとしても，プラズマや試料の有無 によってインピーダンスが逐次変化するため, 今回のよう な方法ではその対応に限界がある。そこで, リアルタイム かつ任意にインピーダンスチューニングができるスタブチ ューナでマグネトロンと共振器を電気的・機械的に直結す れば, 微妙なインピーダン久整合が可能になる. 現在, こ のような同軸型ダブル・スタブチューナを設計, 製作して 打り，有効性を検討中である。

\section{謝辞}

本研究の遂行にあたり, 実験方法に関して愍切丁寧なご 指導を頂いた本学大学院生, 蓮井秀朝氏（現東レエンジニ アリング株式会社）に厚く御礼申し上げます。さらに本研 究の一部は平成 8 年度阿波銀行学術. 文化振興財団の助 成を受けて行われて抢り，ここに感謝の意を表します。

\section{文献}

1) C. I. M. Beenakker: Spectrochim. Acta 31B, 483 (1976).

2) A. B-Kamara and E. G. Codding: Spectrochim. Acta 36B, 973 (1981).

3) 沖野, 宮武, 内田, 南: 分光研究 42,289 (1993).

4) 沖野, 宮武, 南, 内田: 分光研究 43, 23 (1994).

5) M. M. Mohamed, T. Uchida, D. M. Coleman, and S. Minami: J. Spectrosc. Soc. Japan 38, 288 (1989). 